\title{
Concerns during initiation of sleeve gastrectomy in a laparoscopic bariatric program: a single surgeon's initial experience and review of latest literature
}

\author{
Abstract \\ Introduction: Among the existing weight-loss procedures, laparoscopic sleeve \\ gastrectomy has gained increasing popularity in the past decade, due to its remarkable \\ results concerning EWL and resolution of comorbidities. However, most of major \\ concerns for a team initiating with sleeve gastrectomy, still remain as subjects of \\ major controversy among authors.
}

Aim: to present a single surgeon's technique and initial results with laparoscopic sleeve gastrectomy and review the latest literature for main concerns of a novice team.

Material: Six patients aged 24-49years, underwent full preoperative workup, including history, physical examination, evaluation from cardiologist, anesthesiologist, as well as clinical dietician and pneumologist. A laparoscopic sleeve gastrectomy was offered as the most suitable bariatric procedure for 5 of the patients. One of the patients underwent a robotic-assisted technique.

Results: All 6 patients followed an uncomplicated course. All patients were assessed for leaks on postoperative day 2 by gastrographin swallow. One patient presented with high fever on postoperative day 4 and was readmitted. No leaks were noted in any of the patients.

Conclusion: Reinforcing the staple line during sleeve gastrectomy by suturing and glue is the routine followed by the authors. Robotics seem to facilitate sleeve gastrectomy, especially during challenging mobilization of the fundus near the spleen as well as during intracorporeal suturing.
Volume 8 Issue I - 2018

Savvas Hirides, Petros Hirides

Athens Medical Center, Greece

Correspondence: Savvas Hirides, Athens Medical Center, Greece,Email savashiridis@gmail.com

Received: January 29, 2018 | Published: February 08, 2018

\section{Introduction}

Among the existing weight-loss procedures, laparoscopic sleeve gastrectomy has gained increasing popularity in the past decade, due to its remarkable results concerning EWL and resolution of comorbidities. Also because it seems fast and easy and doesn't have the burden of often visits and adjustments as it used to be with the cases of gastric banding. However, most of major concerns for a team initiating with sleeve gastrectomy, still remain subjects of major controversy among authors. Our aim in this paper is to present a single surgeon's technique and initial results with laparoscopic sleeve gastrectomy and review the latest literature for main concerns of a novice team.

\section{Material}

In 2007 the authors joined a fellowship program at an IFSOaccredited private clinic in Athens Medical Center, Greece with large experience in gastric banding, sleeve gastrectomy and robotic bariatric redo cases. In 2009 they became part of this clinical team and gained experience from 114 laparoscopic and robotic bariatric cases in the period 2009-2017. Based on this experience, the authors initiated their own bariatric program in the same institution, at first with adjustable gastric banding placement and band removals and then with sleeve gastrectomies.

Six patients aged 24-49years, underwent full preoperative workup, including history, physical examination, evaluation from bariatric surgeon, cardiologist, anesthesiologist, as well as clinical dietician and pneumologist. A laparoscopic sleeve gastrectomy was offered as the most suitable bariatric procedure. One of the patients underwent a robotic-assisted laparoscopic sleeve combined with cholecystectomy. All patients signed an informed consent for the procedure. Two patients denied blood transfusion in the remote case of intraoperative bleeding due to religious reasons. Perioperative thromboprophylaxis is performed as a routine by our team using LMW heparin according to body weight.

\section{Surgical technique}

Patient is positioned supine in steep anti-Trendelenburgh with pressure garments on the lower extremities. Entrance to the peritoneal cavity is achieved by means of an optiview trocar but in case of difficulty we usually use an open Hasson technique. A 5-port approach $(5 \mathrm{~mm}$ to $15 \mathrm{~mm})$ is routinely used. After exploration of the abdomen and reassessment of liver size, a constant distance of $6 \mathrm{~cm}$ from the gastric pylorus is measured along the greater curvature. At this point, division of the gastrocolic ligament with laparoscopic ultrasonic scissors (articulated vessel sealer in robotic technique) takes place and entrance in the omental bursa is achieved. Following that, division of the short gastric vessels is initiated. This is usually more challeging as we move proximally towards the spleen and the angle of HIS. Most of the times the fundus is firmly attached to the upper pole of the spleen and procedure is most challenging at this point in the narrow, fatty operative field often anticipated in these patients. After mobilisation of the angle of HIS, recognition of the left crus and preservation of the blood supply of this area, we 
move on with mobilisation of the pancreatic fold. After that, the anesthesiologist introduces a $36 \mathrm{Fr}$ bougie and we facilitate its course down to the pyloric opening. Through the right $12 \mathrm{~mm}$ trocar we introduce the linear endoGIA stapler and initiate the firings guided by the bougie. This maneuver ensures that the sleeve will become narrow enough, without risk for stenosis; it is of great value when cutting near the angle of the stomach. We routinely use a batterypowered linear stapler (one green, one gold and three or four blue cartridges) which offers a stable and perfectly linear cut of the tissue. Gastric resection takes place carefully in order to avoid twisting of the staple line. The most proximal firing is performed along the angle of HIS while trying to protect the blood supply of the area. Following that, suture line reinforcement takes place starting proximally and moving distally along the cut margin of the stomach. Suturing is performed intracorporeally using a 3-0 continuous barbed suture and laparoscopic needle holders (articulated robotic needle holders in the robotic technique). In addition, fibrin sealant is spread over the reinforced line with a laparoscopic applicator. After that we check for leaks using two methods: first, we put the patient in Trendelenburgh position and fill the upper abdomen with normal saline. Then, we introduce air through the nasogastric tube while closing the distal stomach. After this test, we remove the air from the stomach and put methylene blue solution through the nasogastric tube while closing the distal stomach as a second test for possible leaks. The specimen is removed through the left $15 \mathrm{~mm}$ incision with a $1.5 \mathrm{~cm}$ extension of it. A negative-pressure Jackson-Pratt drain is routinely used for 7 days postoperatively. Typical cholecystectomy with ligation of cystic duct and cystic artery, and detachment of the gallbladder from the liver bed, was performed at the same setting in one of our patients (Figures 1-3).

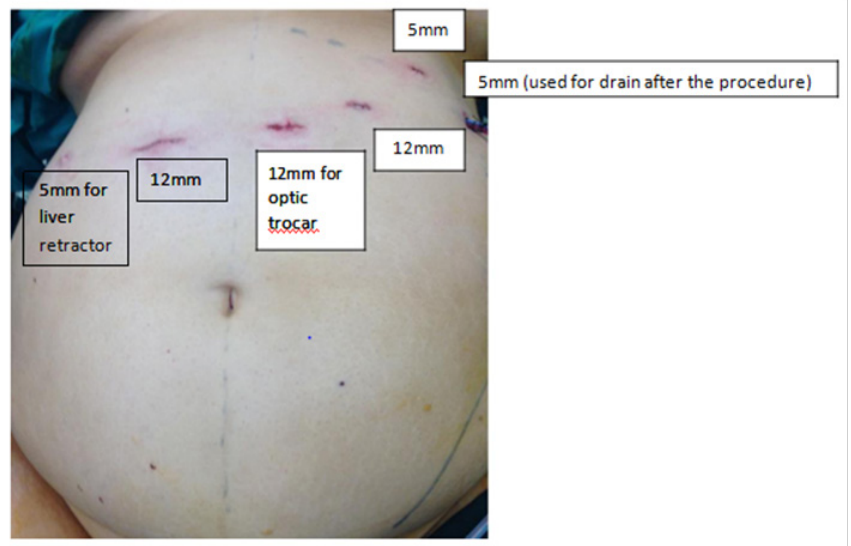

Figure I Positioning of trocars.

\section{Results}

There were no intraoperative episodes of bleeding, any need for trasnfusion or any other intraoperative complication. In our first patient the firings near the gastroesophageal junction left a rather large proximal gastric pouch. This was managed by invaginating the excess tissue in the suturing line during oversewing. All 6 patients followed an uncomplicated postoperative course. They all underwent a gastrographin swallow on the $2^{\text {nd }}$ postoperative day which confirmed the correct shape of the sleeve and excluded leaks and stenoses. No leaks were noted in any of the patients. Nasogastric tube was removed on day 2 and drain removed on postoperative day 7. Patients were discharged on postoperative days 3-5. One of our patients had a minor infection in the subumbilical incision. Another patient presented with fever on postoperative day 4 . This led us to immediate readmission and CT scan with per os contrast medium. Although alarming, her fever was most probably related to transient upper splenic pole ischemia, which was identified in CT. Fever subsided spontaneously within 24hours and the patient was discharged (Table 1). On follow up, all patients declared satisfied by the rate of weight loss, although one patient (a sweet eater) remained stable with her weight one year after surgery (Figure 4).

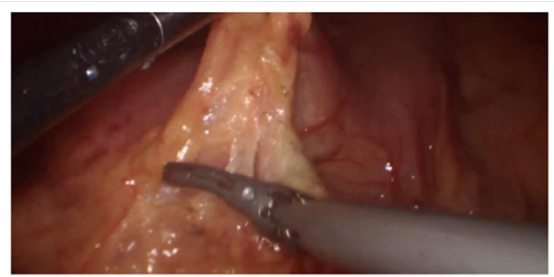

Figure 2a Opening gastrocolic ligament into omental bursa.

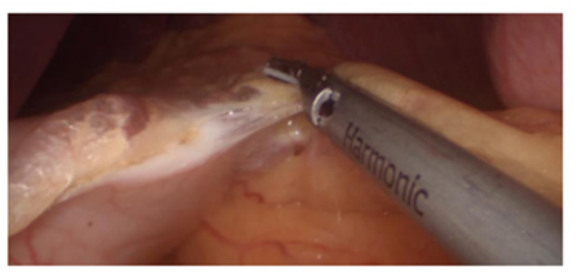

Figure 2b Division of short gastric vessels with ultracision.
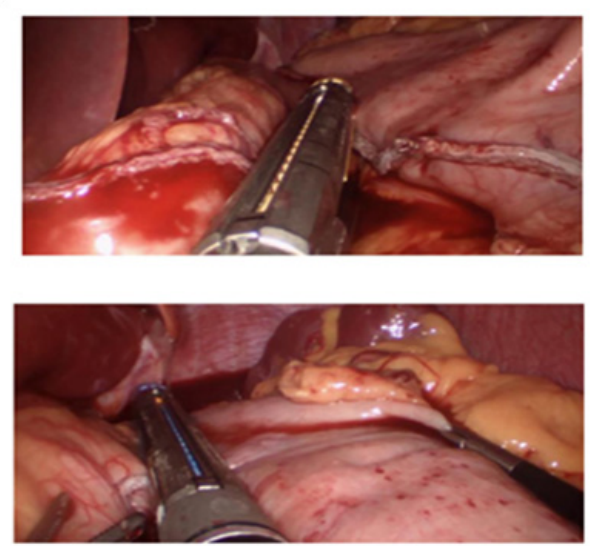

Figure 2c \& 2d Division of stomach with the endoGIA linear stapler.

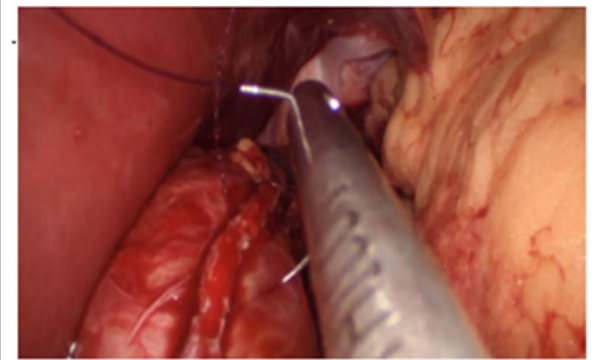

Figure 2e Oversewing the staple line.

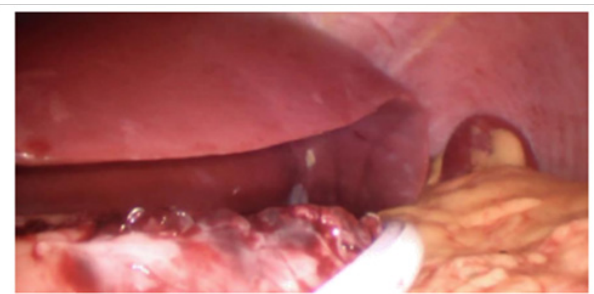

Figure $2 \mathrm{f}$ Placement of Jackson-Pratt drain.

Figure 2 Basic steps of procedure. 


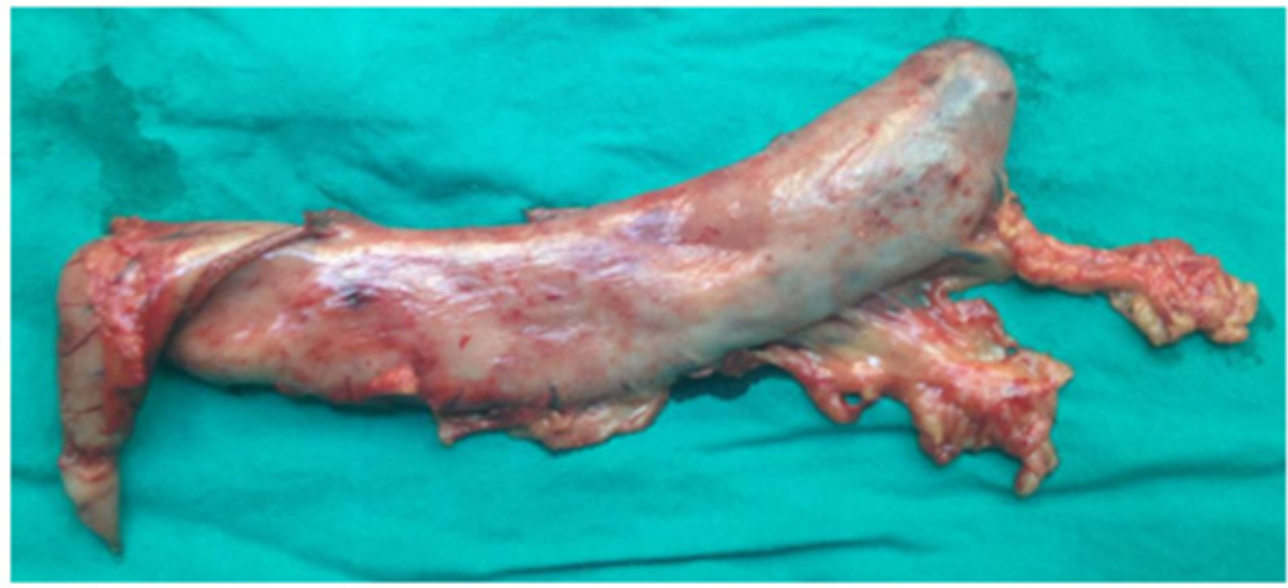

Figure 3 Specimen.

Table I Initial personal LSG series. Preoperative and postoperative weights and BMls and follow up summaries.

\begin{tabular}{|c|c|c|c|c|c|c|c|c|c|c|c|c|c|}
\hline Patient & $\begin{array}{l}\text { Age } \\
\text { at } \\
\text { OP }\end{array}$ & $\begin{array}{l}\text { Initial } \\
\text { BW }\end{array}$ & $\begin{array}{l}\text { Initial } \\
\text { Height }\end{array}$ & $\begin{array}{l}\text { Initial } \\
\text { t BMI }\end{array}$ & $\begin{array}{l}\text { Follow } \\
\text { up }\end{array}$ & $\begin{array}{l}\text { Current } \\
\text { BW }\end{array}$ & $\begin{array}{l}\text { Current } \\
\text { BMI }\end{array}$ & $\begin{array}{l}\text { Comorbidity } \\
\text { Resolution }\end{array}$ & Complications & $\begin{array}{l}\text { Dietary } \\
\text { Modifications }\end{array}$ & Exercise & Other & $\begin{array}{l}\text { Patient } \\
\text { Satisfaction }\end{array}$ \\
\hline \#I & 49 & 122 & 165 & 44.82 & $\begin{array}{l}2 \\
\text { years }\end{array}$ & 83 & 30.49 & $\begin{array}{l}\text { Joint pains } \\
\text { and } \\
\text { Sjogren } \\
\text { symptoms } \\
\text { improved }\end{array}$ & No vomiting. & $\begin{array}{l}\text { Only } \\
\text { amount. } \\
\text { Quality of } \\
\text { food } \\
\text { remained the } \\
\text { same. } \\
\text { Sweet-eater. No } \\
\text { changes } \\
\text { during } \\
\text { alcohol } \\
\text { consumption }\end{array}$ & $\begin{array}{l}\text { For short } \\
\text { period after } \\
\text { the } \\
\text { operation. } \\
\text { Stopped } \\
\text { due to } \\
\text { trigeminal } \\
\text { neuralgia. }\end{array}$ & $\begin{array}{l}\text { History of } \\
\text { esophagitis. } \\
\text { Developed } \\
\text { gallstones } \\
\text { postoperatively. } \\
\text { Cannot } \\
\text { tolerate } \\
\text { junk food } \\
\text { postop. }\end{array}$ & $\begin{array}{l}\text { Very } \\
\text { satisfied }\end{array}$ \\
\hline \#2 & 22 & 110 & 168 & 38.9 & $\begin{array}{l}1,5 \\
\text { year }\end{array}$ & 62 & 21.97 & $\begin{array}{l}\text { Less pain } \\
\text { during } \\
\text { menstruation. }\end{array}$ & $\begin{array}{l}\text { Postop fever } \\
\text { on DAY\#4 - } \\
\text { upper pole } \\
\text { spleen } \\
\text { ischemia }\end{array}$ & & $\begin{array}{l}\text { Requested } \\
\text { avoidance } \\
\text { of blood } \\
\text { transfusion }\end{array}$ & $\begin{array}{l}\text { No excess } \\
\text { skin }\end{array}$ & $\begin{array}{l}\text { Very } \\
\text { satisfied }\end{array}$ \\
\hline \#3 & 23 & 147 & 190 & 40.7 & $\begin{array}{l}\text { I } \\
\text { year }\end{array}$ & 89 & 24.6 & $\begin{array}{l}\text { Resolution } \\
\text { of knee } \\
\text { pains } \\
\text { during first } \\
\text { month. } \\
\text { Resolution } \\
\text { of high TG } \\
\text { and } \\
\text { Cholestero } \\
\text { I levels. }\end{array}$ & & $\begin{array}{l}\text { Intolerance to } \\
\text { alcohol. }\end{array}$ & $\begin{array}{l}\text { Requested } \\
\text { avoidance } \\
\text { of blood } \\
\text { transfusion }\end{array}$ & $\begin{array}{l}\text { Fastest } \\
\text { Weight Loss } \\
-23 \mathrm{~kg} \text { in } \\
\text { first month. } \\
\text { No excess } \\
\text { skin }\end{array}$ & $\begin{array}{l}\text { Very } \\
\text { satisfied }\end{array}$ \\
\hline$\# 4$ & 34 & 115 & 168 & 40.75 & $\begin{array}{l}5 \\
\text { months }\end{array}$ & 88 & 31.18 & $\begin{array}{l}\text { Borderline } \\
\text { glucose } \\
\text { and } \\
\text { cholesterol } \\
\text { levels } \\
\text { corrected. } \\
\text { Gastric } \\
\text { ulcers } \\
\text { prior to } \\
\text { surgery. }\end{array}$ & $\begin{array}{l}\text { Mild wound } \\
\text { infection. } 3 \\
\text { months of } \\
\text { gastric pains } \\
\text { and frequent } \\
\text { vomiting } \\
\text { after eating } \\
\text { meat. Excess } \\
\text { skin not } \\
\text { remarkable. }\end{array}$ & $\begin{array}{l}\text { Reduced } \\
\text { carbsalthough } \\
\text { she lives } \\
\text { abroad and } \\
\text { works really } \\
\text { hard so diet } \\
\text { is not } \\
\text { always } \\
\text { appropriate. } \\
\text { Still eats a } \\
\text { lot of snacks at } \\
\text { work. } \\
\text { No binge } \\
\text { Eating anymore }\end{array}$ & $\begin{array}{l}\text { Increased. } \\
\text { Pilates } \\
\text { reformer } \\
\text { helped her } \\
\text { Significantly. }\end{array}$ & $\begin{array}{l}\text { She was } \\
\text { enthusiastic } \\
\text { about her } \\
\text { clothes size: } \\
\text { from } 20 \text { - } \\
22 \text { UK to I2- } \\
\text { I4 (ie from } \\
\text { XXL to } \\
\text { MEDIUM) }\end{array}$ & $\begin{array}{l}\text { Says she } \\
\text { doesn't } \\
\text { regret doing } \\
\text { the } \\
\text { operation. } \\
\text { Wishes to } \\
\text { have } \\
\text { undergone } \\
\text { it even } \\
\text { earlier. }\end{array}$ \\
\hline
\end{tabular}


Table Continued....

\begin{tabular}{|c|c|c|c|c|c|c|c|c|c|c|c|c|c|}
\hline Patient & $\begin{array}{l}\text { Age } \\
\text { at } \\
\text { OP }\end{array}$ & $\begin{array}{l}\text { Initial } \\
\text { BW }\end{array}$ & $\begin{array}{l}\text { Initial } \\
\text { Height }\end{array}$ & $\begin{array}{l}\text { Initial } \\
\text { BMI }\end{array}$ & $\begin{array}{l}\text { Follow } \\
\text { up }\end{array}$ & $\begin{array}{l}\text { Current } \\
\text { BW }\end{array}$ & $\begin{array}{l}\text { t Current } \\
\text { BMI }\end{array}$ & $\begin{array}{l}\text { tComorbidity } \\
\text { Resolution }\end{array}$ & Complications & $\begin{array}{l}\text { Dietary } \\
\text { Modifications }\end{array}$ & Exercise & Other & $\begin{array}{l}\text { Patient } \\
\text { Satisfaction }\end{array}$ \\
\hline$\# 5$ & 35 & 150 & 172 & 50.84 & $\begin{array}{l}14 \\
\text { months }\end{array}$ & 122 & 41.35 & $\begin{array}{l}\text { Resolution } \\
\text { of joint } \\
\text { pains }\end{array}$ & $\begin{array}{l}\text { Painful } \\
\text { wounds for } \\
\text { ten days } \\
\text { postoperative. }\end{array}$ & $\begin{array}{l}\text { Reduced } \\
\text { junk food. }\end{array}$ & Increased & & $\begin{array}{l}\text { Very } \\
\text { satisfied }\end{array}$ \\
\hline \#6 & 59 & 135 & 169 & 47.2 & $\begin{array}{l}6 \\
\text { months }\end{array}$ & 105 & 36.7 & $\begin{array}{l}\text { Resolution } \\
\text { of glucose } \\
\text { intolerance. } \\
\text { Normalizat } \\
\text { ion of } \\
\text { blood } \\
\text { pressure }\end{array}$ & $\begin{array}{l}\text { Vomiting } \\
\text { during first } 3 \\
\text { weeks }\end{array}$ & $\begin{array}{l}\text { Reduced } \\
\text { carbonated } \\
\text { beverages }\end{array}$ & Increased & $\begin{array}{l}\text { Robotic } \\
\text { case (plus } \\
\text { cholecystect } \\
\text { omy) }\end{array}$ & $\begin{array}{l}\text { Very } \\
\text { satisfied }\end{array}$ \\
\hline
\end{tabular}

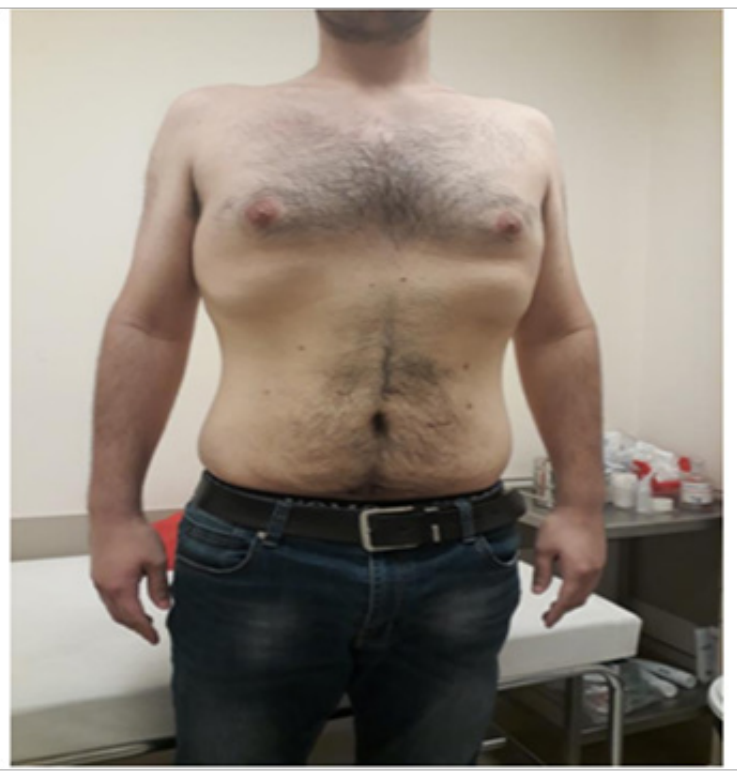

Figure 4 Postoperative result 6 months after Sleeve (patient \#3).

\section{Discussion and literature review}

Sleeve gastrectomy was born out of the first phase of Marceau's BPD/DS operation, and from 1993 it was evolved by Michelle Gagner to an effective stand-alone bariatric procedure.

There are numerous studies comparing surgery for obesity to conservative measures. A new retrospective cohort study with a total of 33,540 patients, showed that bariatric procedures (including bands, sleeves and bypasses) were superior to conservative measures. Bariatric surgery was associated with significantly lower mortality rates from all causes, in a medium follow-up of 4.5 years. ${ }^{1}$ All of the patients in our series had a history of failed attempts with conservative treatments prior to surgery.

\section{Effects of sleeve gastrectomy}

Many recent publications reassess the miscellaneous effects of sleeve gastrectomy. A recent study from Tovar and Bozhychko shows the changes in frequency intake of food in patients undergoing sleeve gastrectomy under a strict dietary control. The authors concluded that problems with food which had been difficult to digest were solved 1year after sleeve. Such foods were meat, bread, vegetables and legumes. Patients in this study gradually decreased dairy products, pasta and rice developing intolerance to them. The decreased intake of unhealthy foods was attributed to strict counseling. ${ }^{2}$ In our experience all of our patients felt 'obliged' to follow a healthy diet after the operation. Four of our patients decreased consumption of unhealthy foods. Two of our patients became very anxious not to regain weight and limited volume of meals as well.

An interesting paper from Acevedo and Eagon illustrated changes in alcohol consumption i.e. an increased blood alcohol concentration after roux-en-y gastric bypass and sleeve gastrectomy. The authors advocate that previous results based on breathalyzer are not considered valid. ${ }^{3}$ Our patients did not notice any changes after alcohol consumption; but they also avoided it anyway. Works of Schiavo et al. tried to assess body composition and resting energy expenditure after sleeve gastrectomy. This subject is very important because loss of fat free mass after sleeve could change the weight maintenance and trigger sarcopenia, with all its related complications in the long term. The authors came to the conclusion that sleeve gastrectomy does not provoke excessive fat free mass depletion. ${ }^{4}$ However a letter from Cecile et al. identified at least three methodological errors in the previous study rendering its conclusions incorrect. ${ }^{5}$ As a result, it seems that the important topic of body composition alterations after sleeve gastrectomy needs further clarification with more studies. A study from St.Louis USA failed to show any difference in the taste perception and eating behavior induced from gastric bypass in comparison to sleeve gastrectomy. In contrast, both operations produced the same beneficial effects on the factors involved in regulation of eating behavior and hedonic part of taste perception. ${ }^{6}$ Our patients did not describe any changes in taste perception.

Sleeve gastrectomy was compared to bypass in the SMBOSS randomized clinical trial. This trial, coming from multiple Swiss centers, with 107 gastrectomies and 110 bypasses showed no significant difference in excess weight loss between the two groups at five years of follow-up. ${ }^{7}$ The Sleeve Pass randomized clinical trial showed that gastric bypass was associated with greater percentage of excess weight loss at 5years, although the difference was not statistically significant. ${ }^{8}$

Effects of sleeve on comorbidities are also remarkable. Recently, Erol and coworkers demonstrated improval of serum lipid levels including decreases in total cholesterol, LDL, triglyceride levels and an increase in HDL cholesterol levels. ${ }^{9}$ Meanwhile, Huang and coworkers published that predicted coronary heart disease risk decreased after sleeve gastrectomy in 870 sleeve patients. Thus early 
bariatric intervention for the high-risk groups is strongly recommended by the authors. ${ }^{10}$ Our patients did not have increased risk of coronary heart disease but three of our patients had a significant improvement in serum cholesterol and triglyceride levels 6months postoperatively. As far as glycemic control and diabetes are concerned, data for benefits after sleeve gastrectomy are still conflicting, suggesting the need for further studies. Sista and associates studied the resolution of type 2 diabetes after sleeve gastrectomy as a two-step hypothesis. Ninety-one sleeve patients were assessed for insulin secretion, insulin resistance, plasma glucose levels and percentage of glycated hemoglobin. Sleeve was found to affect glucose homeostasis via two different time-related modes: first with hormonal changes and secondly with the percentage of excess weight loss as a determining factor for the end metabolic result. ${ }^{11}$

Compared to gastric bypass, sleeve exhibited similar effects on glycemic control despite lower GLP-1 levels and inferior BMI decrease..$^{12}$ Insulin resistance was improved while GLP-1 and Ghrelin was changed significantly in type 2 diabetes prior to weight loss in both groups. HOMA IR decreased to less than the cut-off value after 3 months and it was close to complete remission. The main mechanism of action was remission of insulin resistance but dietary factors played also a significant role. ${ }^{13}$

\section{Technique}

Technical aspects of sleeve gastrectomy procedure are often a matter of controversy among authors. Assessment of learning curves in a big study with 500 patients showed that the institutional learning process stabilisation point in a newly established bariatric center is between the 100 and 200 operation. Prior to this, morbidity rates were high, a fact that should raise concerns to surgeons willing to start performing their first sleeve gastrectomy cases without experienced guidance. ${ }^{14}$

Concerning the bougie size, a systematic review and meta-analysis from Wang and co-workers supports that bougie size should not exceed 36Fr. Some researchers support that bougie size below $32 \mathrm{Fr}$ may increase the possibility of strictures. ${ }^{15}$ Concerning the shape of sleeve, a study from Saleh showed a tendency for decreased reflux and improved weight loss in the lower pouch shape group, regardless of the calibration device. ${ }^{16}$ Preliminary results from a randomized trial reported a global tendency for accelerated gastric emptying after sleeve, although there were no differences in weight loss in either antrum preservation or antrum resection groups. ${ }^{17}$ Oversweing of the staple line is still a matter of great controversy, while in a recent study with 200 patients the staple line bleeding rate was significantly lower in the oversewing group of patients and the authors support the method as a non expensive and easy way to protect for bleeding, although it should be performed by an experienced surgeon to avoid the complications related to the seroserotomy suturing. ${ }^{18}$ In our experience, oversweing is greatly facilitated by the robotic system, if this is available in the institution. anagement of hiatal hernias during sleeve gatrectomy is still a matter of great debate among authors. Recent studies show that patients with hiatal hernia and reflux experience significant symptom improvement after cruroplasty with buttressing of the crurae during sleeve gastrectomy. ${ }^{19}$

\section{Innovations}

Stapleless technique as a means of a more affordable alternative has been recently introduced by Mateo Catanzano. ${ }^{20}$ Single port bariatric surgery needs further evaluation, although reproducible techniques have been already described..$^{21}$ Robotic surgery may offer a future advantage in the setting of single port approaches, with its new intuitive single port platform coming up in the end of 2018 . However use of robotics in bariatric surgery needs further evaluation in order to find its proper role. Arecent systematic literature search included 16 studies with 29,787 cases. Use of the robot was associated with increased operative times and length of stay, while leakage, bleeding, infections and excess weight loss were comparable between the two groups. Costs have been found to be higher with the robotic approach. ${ }^{22}$ Our experience shows that in centers with active robotic surgery program from other teams, the robot is very useful in bariatric cases because it facilitates work in narrow spaces, it overcomes the large liver and heavy abdominal wall lifting issues, and offers an ideal suturing platform for procedures involving intracorporeal suturing.

\section{Clinical considerations}

Early discharge after sleeve is related to several factors both clinical and operative. Early operating room start times and treated obstructive sleep apnea positively influenced early discharge. In contrast preoperative opioid use, psychiatric illness, chronic kidney disease and revision cases were associated with delayed discharge. ${ }^{23}$ Another study showed that BMI over 50 in sleeve gastrectomy patients compared to bypass was associated with increased risk of failure to discharge on day 1 . In the same study early discharge on post-operative day 1 was safe and not associated with greater risk for readmission. ${ }^{24}$ Our patients were all discharged between postoperative day 3 and 5 .

\section{Complications}

Concerning early complications, one of our patient had a minor infection in the subumbilical incision. Another patient presented with fever $\left(38.3^{\circ}\right)$ on postoperative day 4 and was readmitted. Fortunately, her fever was due to splenic arterial demarcation of the upper pole of spleen. Splenic arterial demarcation has been observed often during sleeve gastrectomy. In a study by Stamou et al., ${ }^{25}$ it was found to happen in $4.1 \%$ of patients. One of the 12 patients in this study raised temperature to 38.5 at the 7 th postoperative day, was also readmitted and discharged on the 10th postoperative day. Splenic discoloration following sleeve is a very uncommon complication with minimal clinical significance which could be related to hematoma, venous congestion or ischemia. Splenic abscess cannot be ruled out. If splenic abscesses do occur, they should be treated with broadspectrum antibiotics because they tend to be polymicrobial. Treatment for solitary abscesses tends to be percutaneous or laparoscopic (drainage) in order to preserve the spleen. Splenectomy is required only if these minimally-invasive options failed. ${ }^{26}$ Delayed intrasplenic abscesses are very rare but bariatric surgeon should be aware of them as a potential complication. Exact causes are still unclear. ${ }^{27}$ Portal mesenteric venous trombosis is a very rare but fatal complication. It is very difficult to diagnose while presenting symptoms are usually non specific. Patients without previous risk factors can be anticoagulated for 3 to 6 months. ${ }^{28}$ Major complications such as bleeding, leakage and gastric stenosis occur in 5\% of cases in large series. Risk of leakage is $2.1 \%$, usually found in the upper part of the staple line. It is the second most common cause of death from sleeve, with mortality rates up to $0.4 \%{ }^{29}$ No major complications in our series. Endoscopic internal drainage either by septotomy or pigtails are discussed nowadays in the management of post sleeve fistulae. It is advised that septotomy should be performed at least one month after surgery. Although drainage is considered the first line of therapy, septotomy is a good option for treatment of organized collections or chronic fistulae. ${ }^{30}$ Use of self expandable metal stents is the most popular endoscopic 
management of post sleeve leaks. Double pigtail plastic stents have also been used with good results. The over-the-scope-clip-system is also a promising endoscopic approach for management of leaks with reported rates of success up to $86 \%$. Stent migration and related ulcers are common after stent placement. ${ }^{31}$

\section{Conclusion}

Numerous parameters have to be taken into account for every young surgeon introducing sleeve gastrectomy in his bariatric surgical program. For many reasons it is the most attractive bariatric procedure today. However, long learning curves have been described in the literature and one should always bear in mind that it may be associated with serious complications such as hemorrhage or leaks, even death of the patient. Reinforcing the staple line by suturing and glue as well as use of negative pressure drain is the routine followed by the authors. Robotics may facilitate sleeve gastrectomy, especially during challenging mobilization of the fundus near the spleen and during reinforcement of the staple line.

\section{Acknowledgements}

None.

\section{Conflict of interest}

The author declares no conflict of interest

\section{References}

1. Reges O, Greenland P, Dicker D, et al. Association of Bariatric Surgery Using Laparoscopic Banding, Roux-en-Y Gastric Bypass, or Laparoscopic Sleeve Gastrectomy vs Usual Care Obesity Management with All-Cause Mortality. JAMA. 2018;319(3):279-290.

2. Ruiz-Tovar J, Bozhychko M, Del-Campo JM, et al. Changes in Frequency Intake of Foods in Patients Undergoing Sleeve Gastrectomy and Following a Strict Dietary Control. Obesity Surgery. 2017;17:30723080

3. Acevedo MB, Eagon JC, Bartholow BD, et al. Sleeve gastrectomy surgery: When 2 alcoholic drinks are converted to 4. Surg Obes Relat Dis. 2017;7289(17):31044

4. Schiavo L, Scalera G, Pilone V, et al. Fat mass, fat-free mass, and resting metabolic rate in weight-stable sleeve gastrectomy patients compared with weight-stable nonoperated patients. Surg Obes Relat Dis 2017;13(10):1692-1699.

5. Bétry C. Misleading conclusions on the effects of sleeve gastrectomy on body composition due to statistical errors. Surgery for Obesity and Related Diseases. 2017;13(11):1932.

6. Nance K, Eagon JC, Klein S, et al. Effects of Sleeve Gastrectomy vs. Roux-en-Y Gastric Bypass on Eating Behavior and Sweet Taste perception in Subjects with Obesity. Nutrients. 2018;10(1):10018.

7. Peterli R, Wölnerhanssen BK, Peters T, et al. Effect of Laparoscopic Sleeve Gastrectomy vs Laparoscopic Roux-en-Y Gastric Bypass on Weight Loss in Patients With Morbid Obesity: The SM-BOSS Randomized Clinical Trial. JAMA. 2018;319(3):255-265.

8. Salminen P, Helmiö M, Ovaska J, et al. Effect of Laparoscopic Sleeve Gastrectomy vs Laparoscopic Roux-en-Y Gastric Bypass on Weight Loss at 5 Years Among Patients With Morbid Obesity: The SLEEVEPASS Randomized Clinical Trial. JAMA. 2018;319(3):241-254.

9. Erol V, Yılmaz TH, Tuncalı B, et al. Changes in serum lipid levels after laparoscopic sleeve gastrectomy in morbidly obese dyslipidemic and normolipidemic patients. Acta Chir Belg. 2017;17:1-6.
10. Huang CC, Wang W, Chen RJ, et al. Predicted Coronary Heart Disease Risk Decreases in Obese Patients After Laparoscopic Sleeve Gastrectomy. World J Surg. 2017;10:29282509.

11. Sista F, Abruzzese V, Clementi M, et al. Resolution of type 2 diabetes after sleeve gastrectomy: a 2-step hypothesis. Surg Obes Relat Dis. 2017;7289(17):31091.

12. Wallenius V, Dirinck E, Fändriks L, et al. Glycemic Control after Sleeve Gastrectomy and Roux-En-Y Gastric Bypass in Obese Subjects with Type 2 Diabetes Mellitus. Obes Surg. 2017;11695:3061.

13. Zhu Y, Sun Z, Du Y, et al. Evaluation of insulin resistance improvement after laparoscopic sleeve gastrectomy or gastric bypass surgery with HOMA-IR. Biosci Trends. 2017;11(6):675-681.

14. Major P, Wysocki M, Dworak J, et al. Analysis of Laparoscopic Sleeve Gastrectomy Learning Curve and Its Influence on Procedure Safety and Perioperative Complications. Obes Surg. 2017;017:3075.

15. Wang Y, Yi XY, Gong LL, et al. The effectiveness and safety of laparoscopic sleeve gastrectomy with different sizes of bougie calibration: A systematic review and meta-analysis. Int J Surg. 2018;49:32-38.

16. Alhaj Saleh A, Janik MR, Mustafa RR, et al. Does Sleeve Shape Make a Difference in Outcomes? Obes Surg. 2018;017:3087.

17. Garay M, Balagué C, Rodríguez-Otero C, et al. Influence of antrum size on gastric emptying and weight-loss outcomes after laparoscopic sleeve gastrectomy (preliminary analysis of a randomized trial). Surg Endosc. 2018;017:5972.

18. Taha $\mathrm{O}$, Abdelaal $\mathrm{M}$, Talaat $\mathrm{M}$, et al. A Randomized Comparison Between Staple-Line Oversewing Versus No Reinforcement During Laparoscopic Vertical Sleeve Gastrectomy. Obes Surg. 2018;28(1):218-225.

19. Balla A, Quaresima S, Ursi P, et al. Hiatoplasty with Crura Buttressing versus Hiatoplasty Alone during Laparoscopic Sleeve Gastrectomy. Gastroenterol Res Pract. 2017;2017:6565403.

20. Catanzano M, Grundy L, Bekheit M. Stapleless Laparoscopic Sleeve Gastrectomy: Reasoning and Technical Insights. Obes Surg. 2017;017:3058.

21. Barranco A, Morales-Conde S, Padillo FJ. Single port-assisted laparoscopic sleeve gastrectomy: a new approach to the growth of reproducibility of the single portretain. Surg Obes Relat Dis. 2017;7289(17):31054.

22. Tasiopoulou VS, Svokos AA, Svokos KA, et al. Robotic versus laparoscopic sleeve gastrectomy: a review of the current evidence. Minerva Chir. 2017;73(1):55-63.

23. Jonsson A, Lin E, Patel L, et al. Barriers to Enhanced Recovery after Surgery after Laparoscopic Sleeve Gastrectomy. J Am Coll Surg. 2018;7515(17):32191

24. Mahmood F, Sharples AJ, Rotundo A, et al. Factors Predicting Length of Stay Following Bariatric Surgery: Retrospective Review of a Single UK Tertiary Centre Experience. Obes Surg. 2018;017:3105.

25. Stamou KM, Menenakos E, Gomatos IP, et al. Clinical implications of sleeve gastrectomy as a source of spleen infarction or ischemia. Obes Surg. 2011;21(10):1490-1493.

26. Singh Y, Cawich S, Aziz I, et al. Delayed splenic abscess after laparoscopic sleeve gastrectomy. BMJ Case Rep. 2015;2015:208057.

27. Nassour F, Schoucair NM. Delayed Intra Splenic Abscess: a Specific Complication Following Laparoscopic Sleeve Gastrectomy. Obes Surg. 2018;28(2):589-593.

28. Ming Tan SB, Greenslade J, Martin D, et al. Portomesenteric vein thrombosis in sleeve gastrectomy: a 10-year review. Surg Obes Relat Dis. 2017;(17):31092. 
29. Silecchia G, Iossa A. Complications of staple line and anastomoses following laparoscopic bariatric surgery. Ann Gastroenterol. 2018;31(1):56-64.

30. Angrisani L, Hasani A, Santonicola A, et al. Endoscopic Septotomy for the Treatment of Sleeve Gastrectomy Fistula: Timing and Indications. Obes Surg. 2017;017:3071.
31. Tsai YN, Wang HP, Huang CK, et al. Endoluminal stenting for the management of leak following sleeve gastrectomy and loop duodenojejunal bypass with sleeve gastrectomy. Kaohsiung J Med Sci. 2018;34(1):43-48 